\title{
The Attitudes of the Young towards Social Media
}

\author{
Alpaslan Baki Ertekin (Corresponding Author) \\ Faculty of Sport Sciences, Istanbul Gelisim University \\ Cihangir M. Sht. Jand. Kom. Er Hakan Öner Sk. No:1 Avcılar, Istanbul, Turkey \\ Tel: 90-212-422-7000Ｅ-mail: abe.akademik@gmail.com \\ Yesim Avunduk \\ Faculty of Economic, Administrative and Social Sciences, Ayvansaray University \\ Ayvansaray Cd. No:45 D:45, 34662 Fatih, Istanbul, Turkey \\ Tel: +902124447696E-mail: yesimavunduk@gmail.com
}

$\begin{array}{ll}\text { Received: September 21, } 2020 & \text { Accepted: October 19, } 2020 \\ \text { Published: November 2, } 2020 & \\ \text { doi:10.5296/jei.v6i2.17753 } & \text { URL: https://doi.org/10.5296/jei.v6i2.17753 }\end{array}$

\begin{abstract}
This study aimed to investigate the attitudes of young individuals towards social media. The study sample consisted of 391 university students studying at different faculties (172 males and 219 females) and with an age average of $22.47 \pm 2.29$. The participants were selected using the appropriate sampling method, which is one of the non-random sampling methods. The data collection tools involved a personal information form and the "Social Media Attitude Scale" developed by Otrar and Argin (2015). Descriptive statistics were applied to determine the distribution of personal information (e.g., frequency, arithmetic mean, standard deviation) and the Shapiro Wilks normality test to check whether the data had a normal distribution. Since the data were appropriate for parametric tests, an independent t-test and ANOVA were applied to find the differences in social media use by specific demographic characteristics. According to the study findings, there was a significant difference in social media use by gender and faculty $(p<0.05)$, but no significant difference was found by age $(p>0.05)$. It was concluded that the participants' attitudes towards social media varied by only gender and faculty.
\end{abstract}

Keywords: Young individuals, Social media attitude, Social media use

\section{Introduction}

Beyond being a network to access information, the Internet has become a medium that 
connects individuals and facilitates the socialization. Social media is one of the most important communication tools today.

The changing and developing technology has converted the communication procedures into a multidimensional, interactive, democratic, and equal patterns rather than a one-dimensional 'transmission' from top to bottom (Tuncer, 2013). Computer and Internet use rate was $59.6 \%$ among 16 years-older, and $72.9 \%$ among 74 years-older in 2018 . These rates were $56.6 \%$ and $66.8 \%$ in 2017, respectively (TSI, 2018). When the purposes of internet use were considered, it was found that $82.4 \%$ used the Internet to create profiles on social media, send messages, or share photos in the first three months of 2016. Besides, $74.5 \%$ used it for watching videos; $69.5 \%$ for reading online news, newspapers, or magazines; $65.9 \%$ for searching health information; $65.5 \%$ for searching about goods and services; and $63.7 \%$ for listening to music (web radio) (TSI, 2016). Today, people are confronted with a new interaction pattern and media that intensely affect societies and individuals in the $21^{\text {st }}$ century when global interaction is peak. It is called "social media" through which individuals are involved in simultaneous interaction, rather than a unilateral connection (Poytner, 2010). The social web applications based on mutual social interaction were typical in web 2.0 network and became popular with Friendster and Myspace in 2002-2003, then Flickr and Youtube in 2004-2005 and Facebook, Twitter, Youtube, and Linkedin in 2006-2007 (Boyd \& Ellison, 2010; Jenkins-Guarnieri et al., 2012). Social network theory is also applied in sociology, anthropology, and psychology and refers to the relationships between network users (Scott, 1991). Social media is based on sharing and communication and integrates technology with words, images, sounds, and videos. Social media is "a common term for online tools and websites that create interaction by providing users with the opportunity to share information, thoughts, interests, and knowledge" (Sayımer, 2008). According to Binark (2014), features such as digitality, interaction, hyper-textuality, and content production by users are the distinctive advantages of social media. The definition and scope of social media tools that integrate technology and social entrepreneurship with photos, videos, and audio files vary from person to person. However, the main elements supported by computers and mobile phones appear in various forms such as blogs, microblogs, online chat, RSS feeds, social networks, social bookmarking sites, forums, podcasts, video sharing sites, and virtual worlds (Hatipoğlu, 2009; Koç \& Karabatak, 2011). Social media is one of the latest ideas that offers opportunities as a new type of online media (Mayfield, 2008). It is known that the users of social networking sites are mostly young adults, but the young generation skillfully uses them in many different areas (ComScore, 2015). Social networking sites are web-based systems that allow individuals to (1) create a public or semi-public profile, (2) help them list other users of the same sites, and (3) share their list of connections (Boyd \& Ellison, 2007). In this sense, although it is a new communication environment and gains new meanings as users show interest in this technology (Vural \& Bat, 2010), it is especially important due to its direct effects on behaviors (Kirschenbaum, 2004). Besides, it has some advantages in affecting other people's behaviors, such as quick feedback (Gilbert \& Karahalios, 2009). Attitudes are not innate, but learned; they are not temporary and provide stability in the relationship between the individual and the object, yet there is also a bias in this relationship (Tavşancıl, 2010). According to the literature, there are many types of research on the purpose and habits of social network use, cultural differences in social media use, the usage patterns of social networks, the 


\section{Macrothink

relationship between social media use and academic success, motivation, and interaction (Ajjan et al., 2008; Mazman, 2009; Matney \& Borland, 2009; Hytten, 2010; Schroeder et al., 2010). In their study, Brady et al. (2010) stated that many lecturers benefitted several social networks such as Facebook, MySpace, and LinkedIn in distance education. This study aimed to examine the students' attitudes from different faculties towards social media by certain variables.

\section{Method}

\subsection{Research Group}

The study sample consisted of 391 volunteer university students (172 males and 219 females), with an average age of $22.47 \pm 2.29$ years. The participant students studied at different faculties and selected with an appropriate sampling method from non-random sampling methods.

\subsection{Data Collection Tools}

A "Personal Information Form" and the "Social Media Attitude Scale" were used as the study's data collection instrument.

\subsection{Personal Information Form}

The researcher developed the form and used to collect data on participants' gender, age, faculty, class level, and social media use.

\subsection{Social Media Attitude Scale}

The "Social Media Attitude Scale" was developed by Otrar and Argin (2015) to measure the social media attitude levels. It is a 5-point Likert type scale consisting of 23 items and four sub-dimensions: sharing necessity, social competence, social isolation, and relation with teachers. The Cronbach Alpha internal consistency coefficient of the scale was 0.85 , and it was 0.80 for the current study.

\subsection{Data Analysis}

Statistical analysis was carried out with the SPSS 20. Descriptive statistics were applied to determine the distribution of personal information (e.g., frequency, arithmetic mean, standard deviation), and the Shapiro Wilks normality test was to find out whether the data had a normal distribution. Once the suitability of the data was confirmed, an independent t-test and ANOVA were performed to describe the differences in social media use of the participants by certain demographic characteristics. 


\section{Results}

Table 1. Distribution of personal information

\begin{tabular}{|c|c|c|c|}
\hline Variables & & $\mathbf{F}$ & $\%$ \\
\hline \multirow{3}{*}{ Gender } & Female & 219 & 56.0 \\
\hline & Male & 172 & 44.0 \\
\hline & Total & 391 & 100 \\
\hline \multirow{4}{*}{ Age } & $17-20$ & 93 & 23.8 \\
\hline & $21-23$ & 226 & 57.8 \\
\hline & 24 years and older & 72 & 18.4 \\
\hline & Total & 391 & 100 \\
\hline \multirow{4}{*}{ Faculty } & Education Faculty & 158 & 40.4 \\
\hline & Sports Faculty & 127 & 32.5 \\
\hline & Fine Arts Faculty & 106 & 27.1 \\
\hline & Total & 391 & 100 \\
\hline \multirow{5}{*}{ Class level } & 1.Sinif & 75 & 19.2 \\
\hline & 2.Sinif & 113 & 28.9 \\
\hline & 3.Sinif & 80 & 20.5 \\
\hline & 4.Sinif & 123 & 31.5 \\
\hline & Total & 391 & 100 \\
\hline \multirow{3}{*}{ Social Media Use } & Yes & 321 & 82.1 \\
\hline & No & 70 & 17.9 \\
\hline & Total & 391 & 100.0 \\
\hline
\end{tabular}

Table 1 shows the statistical findings of personal information. According to the analysis results, $56.0 \%$ of the participants were male, $57.8 \%$ were $21-23$ years old, $40.4 \%$ were studying at "Education Faculty," $31.5 \%$ were 4 th class, and $82.1 \%$ used social media. 
Table 2. Distribution of the scores by gender

\begin{tabular}{|c|c|c|c|c|c|}
\hline Sub-dimension & Gender & $\mathbf{N}$ & Avg. \pm Sd. & $\mathbf{t}$ & $\mathbf{P}$ \\
\hline \multirow{2}{*}{ Social Competence } & Female & 219 & $3.46 \pm .94$ & \multirow{2}{*}{2.749} & \multirow{2}{*}{$.006 *$} \\
\hline & Male & 172 & $3.20 \pm .91$ & & \\
\hline \multirow{2}{*}{ Sharing Necessity } & Female & 219 & $2.48 \pm .76$ & \multirow{2}{*}{-2.329} & \multirow{2}{*}{$.020 *$} \\
\hline & Male & 172 & $2.26 \pm .79$ & & \\
\hline \multirow{2}{*}{ Relation with Teachers } & Female & 219 & $3.19 \pm 1.14$ & \multirow{2}{*}{.366} & \multirow{2}{*}{.715} \\
\hline & Male & 172 & $3.15 \pm 1.10$ & & \\
\hline \multirow{2}{*}{ Social Isolation } & Female & 219 & $3.40 \pm .96$ & \multirow{2}{*}{2.299} & \multirow{2}{*}{$.022 *$} \\
\hline & Male & 172 & $3.20 \pm .92$ & & \\
\hline
\end{tabular}

Table 2 demonstrates the scale scores by gender. In this sense, a significant difference was found "Social Competence," "Sharing Necessity," and "Social Isolation" sub-dimensions ( $<$ 0.05). The average scores of female participants were higher than male participants in these sub-dimensions.

Table 3. Distribution of the scores by age

\begin{tabular}{|c|c|c|c|c|c|}
\hline Sub-dimension & Age & $\mathbf{N}$ & Avg. \pm Sd. & $\mathbf{F}$ & $\mathbf{P}$ \\
\hline \multirow{3}{*}{ Social Competence } & $17-20$ years & 93 & $3.31 \pm .92$ & \multirow{3}{*}{1.432} & \multirow{3}{*}{.240} \\
\hline & $21-23$ years & 226 & $3.41 \pm .90$ & & \\
\hline & 24 years and older & 72 & $3.20 \pm 1.03$ & & \\
\hline \multirow{3}{*}{ Sharing Necessity } & $17-20$ years & 93 & $2.39 \pm .84$ & \multirow{3}{*}{.530} & \multirow{3}{*}{.595} \\
\hline & 21-23 years & 226 & $2.40 \pm .72$ & & \\
\hline & 24 years and older & 72 & $2.29 \pm .79$ & & \\
\hline \multirow{3}{*}{ Relation with Teachers } & $17-20$ years & 93 & $3.30 \pm 1.16$ & \multirow{3}{*}{1.737} & \multirow{3}{*}{.177} \\
\hline & $21-23$ years & 226 & $3.18 \pm 1.08$ & & \\
\hline & 24 years and older & 72 & $2.97 \pm 1.21$ & & \\
\hline \multirow{3}{*}{ Social Isolation } & $17-20$ years & 93 & $3.30 \pm .95$ & \multirow{3}{*}{2.212} & \multirow{3}{*}{.111} \\
\hline & $21-23$ years & 226 & $3.40 \pm .95$ & & \\
\hline & 24 years and older & 72 & $3.14 \pm .91$ & & \\
\hline
\end{tabular}


Table 3 includes the distribution of scale scores by age variable. According to the analysis results, although the 21-23 years old participant had high average scores in all sub-dimensions, no statistically significant difference was found $(\mathrm{p}>0.05)$.

Table 4. Distribution of the scores by social media use

\begin{tabular}{|c|c|c|c|c|c|}
\hline Sub-dimension & Social Media Use & $\mathbf{N}$ & Avg. \pm Sd. & $\mathbf{t}$ & $\mathbf{P}$ \\
\hline \multirow{2}{*}{ Social Competence } & Yes & 321 & $3.23 \pm .94$ & \multirow{2}{*}{-2.005} & \multirow{2}{*}{$.046 *$} \\
\hline & No & 70 & $3.42 \pm .92$ & & \\
\hline \multirow{2}{*}{ Sharing Necessity } & Yes & 321 & $2.36 \pm .77$ & \multirow{2}{*}{.272} & \multirow{2}{*}{.780} \\
\hline & No & 70 & $2.38 \pm .76$ & & \\
\hline \multirow{2}{*}{ Relation with Teachers } & Yes & 321 & $3.09 \pm 1.11$ & \multirow{2}{*}{-1.167} & \multirow{2}{*}{.244} \\
\hline & No & 70 & $3.22 \pm 1.13$ & & \\
\hline \multirow{2}{*}{ Social Isolation } & Yes & 321 & $3.23 \pm .96$ & \multirow{2}{*}{-1.719} & \multirow{2}{*}{.086} \\
\hline & No & 70 & $3.40 \pm .93$ & & \\
\hline
\end{tabular}

Table 4 presents the distribution of scores by social media use. There was a significant difference only in the "Social Competence" sub-dimension $(p<0.05)$. The average scores of the participants who did not use social media were higher than the other participants.

\section{Discussion and Conclusion}

Social media is a means of entertainment, relaxation, and leisure activity, offering many opportunities such as sending or receiving messages, following the agenda and accessing information. Daily errands have become dependent on the Internet and social media. According to the results of the current study, males used social media more than females. According to Yetiş (2018), Koçer (2012), and Batıgün and Kılıç (2011), male university students used the Internet more frequently than females, which supports the current findings. However, in their studies, Kaymak (2012), Balcı and Tiryaki (2014), Altunbaş and Kul (2015), and İnce and Koçak (2017) found that females used social media more frequently than males. Besides, Akyüz (2018), Doğruluk (2017), Akçay (2011), and Toruk (2007) emphasized that the attitudes towards social media did not vary by gender.

According to the analysis results, there were significant differences in the sub-dimensions of "Social Competence," "Sharing Necessity," and "Social Isolation." The average scores of female participants were higher than male participants. Argın (2013) and Akyüz (2018) found a statistically meaningful difference in social isolation and social competence sub-dimensions and indicated that females' average scores were higher than males by social isolation sub-dimension, which is parallel to the current study. They also showed that males scored 
higher than females in the social competence sub-dimension. According to the study data, $82.1 \%$ of the participants used social media. This rate was $97.6 \%$ in the study by Solmaz et al. (2013). Ince and Koçak (2017) investigated university students' social media habits at Necmettin Erbakan University and concluded that the more university students spent time on the Internet daily, the higher dependence on social media they developed. It is found that young individuals considered certain websites or computer and mobile phone applications as social media means. That proves that they did not fully grasp the concept of "social media." They also suggested that Facebook was the most popular application among participant university students (93.3\%) (Erol \& Hassan, 2014; Solmaz et al., 2013). In his study, Güney (2018) listed the most frequently visited social media application among the teacher candidates as Instagram, Whatsapp, and Facebook, respectively. A large part of Turkey's population consists of young individuals, and Internet use and social media applications have remarkably risen. Since young people mostly use those applications, it is not surprising that Turkey has become the top country in the world by social media usage rates. However, it is stressed that young people should be assisted to benefit these networks for beneficial purposes (Aydin, 2016). The increasing frequency of social media use among students for many useful purposes such as chat, game, and sharing objects/news also increased social media addiction. Thus, it is concluded that high rates of social media use to achieve specific goals and get satisfaction among students leads to social media addiction (Tutgun Ünal, 2015). It is suggested to use the challenges and criticisms shared on social networks to improve and develop those applications (Yağmurlu, 2011).

\section{References}

Ajjan, H., \& Hartshorne, R. (2008). Investigating faculty decisions to adopt Web 2.0 technologies: Theory and empirical tests. The Internet and Higher Education, 11(2), 71-80. https://doi.org/10.1016/j.iheduc.2008.05.002

Akçay, H. (2011). Kullanımlar ve doyumlar yaklaşımı bağlamında sosyal medya kullanımı: Gümüşhane Üniversitesi üzerine bir araştırma. Illetişim Kuram ve Araştırma Dergisi, 33, 137-161.

Akyüz, A. (2018). Üniversite Öğrencilerinin Sosyal Medyaya İlişkin Tutumları İle Aile Iç̧i İletişim ve Yalnızlı Algısı Arasındaki İlişkinin Değerlendirilmesi (Üsküdar Üniversitesi Sosyal Bilimler Enstitüsü, Klinik Psikoloji Anabilim Dalı, Yüksek Lisans Tezi).

Altunbaş, F., \& Kul, M. (2015). Üniversite Öğrencilerinin Sosyal Medya Kullanımlarına Yönelik Bir Araştırma: Van Yüzüncü Yıl Üniversitesi Örneği. Akademik Bakış Uluslararası Hakemli Sosyal Bilimler Dergisi, 51, 414-423.

Argın, F. S. (2013). Ortaokul Ve Lise Öğrencilerinin Sosyal Medyaya İlişkin Tutumlarının Incelenmesi (Yayımlanmış Yüksek Lisans Tezi, Yeditepe Üniversitesi, Sosyal Bilimler Enstitüsü, İstanbul).

Aydın, İ. E. (2016). Üniversite Öğrencilerinin Sosyal Medya Kullanımları Üzerine Bir Araştırma: Anadolu Üniversitesi Örneği. Selçuk Ün. Sos. Bil. Ens. Der., 35, 373-386. 


\section{I Macrothink}

Journal of Educational Issues

ISSN 2377-2263

2020, Vol. 6, No. 2

Balc1, Ş., \& Tiryaki, S. (2014). Facebook addiction among high school students in Turkey (pp. 120-134). 10th Academic Conference, The International Institute of Social and Economic Sciences, June 3-6, 2014, Vienna, Austria.

Batıgün, A. D., \& Kılıç, N. (2011). İnternet Bağımlılığı ile Kişilik Özellikleri, Sosyal Destek, Psikolojik Belirtiler ve Bazı Sosyo-Demografi k Değişkenler Arasındaki İlişkiler, Türk Psikoloji Dergisi, 26(67), 1-10.

Binark, M. (2014) Yeni Medya Çalışmalarında Araştırma Yöntem ve Teknikleri. İstanbul: Ayrıntı Yayınları.

Boyd, D. M., \& Ellison, N. B. (2007). Social Network Sites: Definition, History, and Scholarship. Journal of Computer-Mediated Communication, 13(1), 210-230. https://doi.org/ 10.1111/j.1083-6101.2007.00393.x

Boyd, D., \& Ellison, N. (2010). Social network sites: Definition, history, and scholarship. IEEE Engineering Management Review, 3(38), 16-31. https://doi.org/10.1109/EMR.2010. 5559139

Brady, K., Holcomb, B., \& Smith, B. (2010). The Use of Alternative Social Networking Sites in Higher Educational Settings: A Case Study of the E-Learning Benefits of Ning in Education. Journal of Interactive Online Learning, 9(2).

ComScore. (2015). Reports Fourth Quarter and Full Year 2015 Result. ComScore, Inc.

Doğruluk, S. (2017). Öğretmen Adaylarının Sosyal Medya Kullanım Alışkanlıkları ile İnternet Bă̆ımlılıkları Arasındaki İlişki (Yüksek Lisans Tezi, Kahramanmaraş Sütçü İmam Üniversitesi Sosyal Bilimler Enstitüsü, Kahramanmaraş).

Erol, G., \& Hassan, A. (2014). Gençlerin sosyal medya kullanımı ve sosyal medya kullanımının tatil tercihlerine etkisi. The Journal of International Social Research, 7(31).

Gilbert, E., \& Karahalios, K. (2009). Predicting Tie Strength with Social Media. CHI'09: Proceedings of the SIGCHI Conference on Human Factors in Computing Systems. https://doi.org/10.1145/1518701.1518736

Güney, B. (2018). Sosyal Bilgiler Öğretmen Adaylarının Sosyal Medya Kullanımlarının Medya Okuryazarlık Düzeyinde Farklı Değişkenler Açısından Incelenmesi (Bursa Uludă̆ Üniversitesi, Eğitim Bilimleri Enstitüsü Türkçe Ve Sosyal Bilimler Ana Bilim Dalı, Sosyal Bilgiler Eğitimi Bilim Dalı, Yüksek Lisans Tezi).

Hatipoğlu, H. B. (2009). Sosyal Medya ve Ticaret Hayatına Etkileri. CIO Club Dergisi, 71-74.

Hytten, K. J. (2010). Facebook's contribution to educationally purposeful activities and college student engagement (Unpublished $\mathrm{PhD}$ Thesis, The University of Vermont, Burlington). Retrieved May 7, 2019, from http://www.ebizmba.com/articles/social-network ing-websites 


\section{Macrothink}

İnce, M., \& Koçak, M. C. (2017). Üniversite Öğrencilerinin Sosyal Medya Kullanım Alışkanlıkları: Necmettin Erbakan Üniversitesi Örneği. Karabük Üniversitesi Sosyal Bilimler Enstitüsü Dergisi, 7(2), 736-749. https://doi.org/10.14230/joiss430

Jenkins-Guarnieri, M. A., Wright, S. L., \& Hudiburgh, L. M. (2012). The relationships among attachment style, personality traits, interpersonal competency, and Facebook use. Journal of Applied Developmental Psychology, 33(6), 294-301. https://doi.org/10.1016/ j.appdev.2012.08.001

Karabacak, E. (1993). Medyanın Tüketici Davranışları Üzerindeki Etkisi ve Pazarlama Yönetimi Açısından Önemi (Selçuk Üniversitesi Sosyal Bilimler Enstitüsü İşletme Anabilim dalı Yüksek Lisans Tezi).

Kaymak, G. (2012). Sanal Topluluklardaki Sosyal Ağlarda Sosyalleşme ve Güven Sorunsalı Ereğli Örneği (Selçuk Üniversitesi Sosyal Bilimler Enstitüsü, Genel Sosyoloji Ve Metodoloji Ana Bilim Dalı, Yüksek Lisans Tezi).

Kirschenbaum, A. (2004), Generic Sources of Disaster Communities: A Social Network Approach. International Journal of Sociology and Social Policy, 24(10/11), 94-129. https://doi.org/10.1108/01443330410791073

Koç, M., \& Karabatak, M. (2011). Sosyal Ağların Öğrenciler Üzerindeki Etkisinin Veri Madenciliği Kullanılarak İncelenmesi. 5 Uluslararası Bilgisayar ve Öğretim Teknolojileri Sempozyumu, Firat Üniversitesi, Elazığ.

Koçer, M. (2012). Erciyes Üniversitesi Öğrencilerinin İnternet ve Sosyal Medya Kullanım Alışkanlıkları. Akdeniz İletişim, 18.

Levine, I., \& Stokes, J. P. (1986). An examination of the relation between individual difference variables to loneliness. Journal of Personality, 54(4), 717-733. https://doi.org/ 10.1111/j.1467-6494.1986.tb00422.x

Matney, M., \& Borland, K. (2009). Facebook, blogs, tweets: How staff and units can use social networking to enhance student learning. Presentation at the Annual Meeting of the National Association for Student Personnel Administrators, Seattle, WA.

Mayfield, A. (2008). What is Social Media? Retrieved May 10, 2019, from http://www. icrossing.co.uk/fileadmin/uploads/eBooks/What_is_Social_Media_iCrossing_ebook.pdf

Mazman, G. (2009). Sosyal ağların benimsenme süreci ve eğitsel bağlamda kullanımı (Yayımlanmamış Yüksek Lisans Tezi). Hacettepe Üniversitesi, Fen Bilimleri Enstitüsü, Ankara.

Otrar, M., \& Argın, F. S. (2015). Öğrencilerin sosyal medyaya ilişkin tutumlarını belirlemeye yönelik bir ölçek geliştirme çalışması. Eğitim ve Öğretim Araştırmaları Dergisi, 4(1), 391-403.

Poytner, R. (2010). The Handbook of Online and Social Research. West Sussex: Johny Wiley \& Sons. 
Sayımer, İ. (2008). Sanal Ortamda Halkla İlişkiler. Beta Yayınları, İstanbul.

Schroeder, A., Minocha, S., \& Schneider, C. (2010). The strengths, weaknesses, opportunities, and threats of using social software in higher and further education teaching and learning. Journal of Computer Assisted Learning, 26, 159-174. https://doi.org/10.1111/j.1365-2729. 2010.00347.x

Scott, J. (1991). Social Network Analysis. Sage Publications, Londra.

Solmaz, B., Tekin, G., Herzem, Z., \& Demir, M. (2013). İnternet ve sosyal medya kullanımı üzerine bir uygulama, Selçuk Illetişim, 7(4).

Tavşancıl, E. (2010). Tutumların Ölçülmesi ve SPSS ile Veri Analizi. Ankara: Nobel Yayın Dağıtım.

Toruk, İ. (2008). Üniversite Gençliğinin Medya Kullanma Alışkanlıkları Üzerine Bir Analiz. Selçuk Üniversitesi Sosyal Bilimler Enstitüsü Dergisi, 19, 475-488.

TUİK. (2016). Hanehalkı Bilişim Teknolojileri (BT) Kullanım Araştırması, Türkiye İstatistik Кигити.

TUİK. (2018). Hanehalkı Bilişim Teknolojileri (BT) Kullanım Araştırması, Türkiye İstatistik Кигити.

Tuncer, S. (2013). Sosyal Medyanın Gelişimi. In Z. Özata (Ed.), Sosyal Medya (pp. 2-25). Anadolu Üniversitesi Yayınları, Eskişehir.

Tutgun Ünal, A. (2015). Sosyal medya bă̆ımlılı̆̆l: üniversite öğrencileri üzerine bir araştırma (Marmara Üniversitesi Sosyal Bilimler Enstitüsü Gazetecilik Ana Bilim Dalı Bilişim Bilim Dalı, Doktora Tezi).

Vural, Z. B. A., \& Bat, M. (2010). Yeni Bir İletişim Ortamı Olarak Sosyal Medya. Ege Üniversitesi İletişim Fakültesine Yönelik Bir Araştırma, Yaşar Üniversitesi Dergisi, İzmir.

Yağmurlu, A. (2011). Kamu yönetiminde halkla ilişkiler ve sosyal medya, Selçuk İletişim, $7(1)$.

Yetiş, Ü. (2018). Üniversite Öğrencilerinin Sosyal Medya Kullanım Alışkanlıkları ile E-Öğrenme Stilleri Arasındaki İlişki (Kahramanmaraş Sütçü İmam Üniversitesi Fen Bilimleri Enstitüsü, Yüksek Lisans Tezi).

\section{Copyright Disclaimer}

Copyright for this article is retained by the author(s), with first publication rights granted to the journal.

This is an open-access article distributed under the terms and conditions of the Creative Commons Attribution license (http://creativecommons.org/licenses/by/3.0/). 